УДК 159.923

DOI https://doi.org/10.32838/2709-3093/2021.3/09

Несправа М.В.

Дніпропетровський державний університет внутрішніх справ

\title{
ОСОБИСТІСНА ХАРАКТЕРИСТИКА СПЕЦАЛЛСТА МІЖНАРОДНИХ ВІДНОСИН ЯК ДЕТЕРМІНАНТА СТИЛЮ УПРАВЛІННЯ
}

У статті розглядається питання особистісних характеристик спеиіаліста міжнародних відносин як детермінанти стилю управління. Наводиться загальна характеристика поняття «стиль управління». Розглядаються три основні стилі управління: авторитарний, демократичний та ліберальний. Наводиться повна психологічна характеристика керівників, яким притаманний авторитарний, демократичний або ліберальний стиль управління. Визначено, ще за авторитарного стилю управління керівник егоїстичний, за демократичного стилю емпатійний, а за ліберального - латентний. 3 метою проведення емпіричного дослідження для вивчення взаємозв'язку стилів управління з особистісними характеристиками спеціалістів міжнародних відносин нами було обрано методику “Велика П'ятірка» для визначення особистісних характеристик спеціалістів, а також опитувальник експертної діагностики стилю управління керівника для визначення стилю управління, притаманного спеціалісту міжнародних відносин. В ході дослідження було визначено, що для більшості опитаних демократичний стиль управління є домінуючим. Це пояснюється тим, що специфіка діяльності спеціалістів міжнародних відносин вимагає демократичного підходу з огляду на те, щзо у світовій практиці демократичні постулати є переважсаючими. Визначено, що загалом вищий рівень проявленості особистісних характеристик за шкалами «Великої П'ятірки» у респондентів, щзо мають більші показники за шкалою демократичного стилю управління, $і$ нижчі показники за шкалами «Великої П'ятірки» у тих респондентів, щзо мають більші показники за шкалою авторитарного стилю управління. Знайдено зв'язки між особистісними характеристиками спеціалістів міжнародних відносин та стилем управління, який їм притаманний. Так, вищими є показники за шкалами екстраверсія (інтроверсія); приязність (обособленість); самоконтроль (імпульсивність); емоційна стійкість (емоиійна нестійкість); експресивність (практичність) у тих спеиіалістів, яким притаманний демократичний стиль управління, а низькі показники за иими шкалами у тих спеціалістів, для яких характерний авторитарний стиль управління. Доведено, що особистісні характеристики спеціаліста міжнародних відносин міцно корелюють зі стилем управління, який їм притаманний, і можуть бути детермінантами стилю управління.

Ключові слова: стиль управління, особистісні характеристики керівника, «Велика П'ятірка», спеціаліст міжнародних відносин, психологія управління.

Постановка проблеми. Управління $є$ невіддільною частиною професійної діяльності спеціалістів різних сфер. Цей процес охоплює планування, організацію, мотивацію і контроль, які необхідні для того, щоб сформулювати і досягти цілей організації.

У системі міжнародних відносин, де спеціаліст має бути виразником інтересів певної групи інших суб'єктів, управління займає одну з передових позицій. Від стилю управління залежить успішність діяльності структури, в якій свою професійну діяльність виконує спеціаліст міжнародних відносин. Керівник у сфері міжнародних відносин повинен вміти створювати сприятливий соціально-психологічний клімат у колективі, заці- кавлювати роботою працівників, застосовувати певні мотиваційні та управлінські методи, виявляти свої лідерські здібності, вміння спілкуватися та вирішувати конфлікти.

Проте $є$ думка, що стиль управління не завжди $€$ категорією, яка приймається відповідно до вимог та умов ситуації, наявні певні предиспозиції щодо того чи іншого стилю управління залежно від особистісних характеристик, які $є$ домінантними у спеціаліста [6].

Аналіз останніх досліджень i публікацій. Проблема формування ефективного стилю управління сьогодні розглядається в міждисциплінарному аспекті, охоплюючи це питання 3 погляду психології, соціології, менеджменту та державного 
управління, а також характеризуючи стиль управління як основну категорію управління персоналом.

Теорію управління розробляли такі науковці, як Р. Блейк і П. Друкер [4]. Теоретичні положення про психологічну структуру спільної діяльності і форми іiі організації розроблені у працях Б.М. Андрушківа [1], А.Л. Журавльова, Б.Ф. Ломова, Р.С. Нємова, М.М. Обозова.

3 1930-х років феномен стилів управління вивчається в менеджменті та соціальній психології. Накопичено великий емпіричний матеріал і побудовано безліч теоретичних моделей, що розрізняють стилі управління за різними ознаками. У своїх працях Р. Блейк та Д. Моутон, М. Виноградський, В. Гладунський, А. Гончаров, О. Донченко, О.С. Кузьмін, К. Левін, Д. Макгрегора, В. Терещенко розкривають сутність поняття «стиль управління», види стилів керівництва, підходи щодо їх вибору.

У працях Ю.I. Арабаджи та I.M. Дашко досліджені питання психологічних особливостей формування ефективного стилю управління менеджера. У дослідженнях А.О. Клочко [7] підіймається питання вивчення особистісних характеристик менеджерів освітніх організацій та їх зв'язок із інноваційними стилями управління.

Проте все ще не дослідженою залишається сфера міжнародних відносин, де стиль управління займає передову роль у сприянні ефективній діяльності організації.

Постановка завдання. Метою статті є дослідження впливу особистісних характеристик спеціалістів міжнародної діяльності на формування стилю управління.

Виклад основного матеріалу. Керівництво, лідерство $є$ тим видом діяльності, який пронизує всю систему управління. Керівництво - важливий компонент ефективного управління. Лідерство це процес, за допомогою якого одна людина впливає на членів групи. Про ефективність лідера в міжнародних відносинах можна судити по тому, яким чином він впливає на інших [3].

Стиль управління як соціально-психологічний феномен має певну структуру, що складається 3 відповідних компонентів. Так, Л. Карамушкою виокремлено шість структурних елементів стилю управління: «рівень значущості для керівника творчої співпраці з колективом; міра орієнтації керівника на налагодження міжособистісних стосунків у колективі, формування колективу; тип спілкування керівника 3 підлеглими; ступінь урахування у процесі управління індивідуальнопсихологічних особливостей працівників i соціально-психологічних характеристик колективу; основні методи впливу на працівників; особливості орієнтації керівника на самого себе» [5].

Для подальшого проведення аналізу необхідним $€$ ознайомлення з психологічною характеристикою основних стилів управління. Змістовною вважаємо характеристику, надану А.О. Клочко [7].

За цією характеристикою керівник, що характеризується авторитарним стилем управління, зазвичай має такі ознаки:

- приймає рішення самостійно;

- не приділяє увагу встановленню позитивного психологічного клімату в колективі;

- спілкується зі співробітниками на принципах «зверхності»;

- не звертає уваги на потреби й інтереси окремих співробітників;

- дає абсолютну перевагу реалізації мети їх колективної діяльності;

- використовує методи командування і наказування;

- агресивно ставиться до критики та не враховує зауваження у процесі організації діяльності.

За демократичного стилю управління керівник:

- вмотивований на колективну діяльність, активну колективну взаємодію у всіх питаннях життєдіяльності команди;

- схильний до колегіального прийняття рішень;

- надає важливого значення встановленню позитивного психологічного клімату в колективі;

- не фокусується на питанні влади, не дотримується «соціальної дистанції» у комунікації, а мотивує до становлення розгалуженої мережі комунікацій у колективі;

- враховує потреби та інтереси кожного співробітника, створює максимальні умови для їхнього задоволення;

- здебільшого користується соціально-психологічними методами впливу;

- самокритичний до оцінки своєї діяльності, iii результатів, власних особистісних характеристик, швидко адаптується до соціальних змін, постійно підвищує свою кваліфікацію.

За ліберального стилю управління керівник:

- не втручається в роботу працівників, дає їм свободу у виконанні своїх функціональних обов'язків;

- не стимулює до активності, проте й не вимагає звітності за виконання дорученої справи;

- індиферентний до встановлення міжособистісних стосунків, створення позитивного психологічного клімату в колективі; 
- не приділяє уваги спілкуванню з підлеглими і не звертає уваги на такі спроби підлеглих;

- байдужий до інновацій;

- в арсеналі методів впливу - пасивне невтручання, спостереження «збоку»;

- байдужий до критики, оскільки вона для нього нічого не означає.

3 цього можемо зробити висновок, що за авторитарного стилю управління керівник егоїстичний, за демократичного - емпатійний, а за ліберального - латентний.

Для дослідження взаємозв'язку стилів управління 3 особистісними характеристиками спеціалістів міжнародних відносин нами було обрано методику «Велика П'ятірка» для визначення особистісних характеристик спеціалістів, а також опитувальник експертної діагностики стилю управління керівника для визначення стилю управління, притаманного спеціалісту міжнародних відносин.

У дослідженні взяли участь 15 осіб - керівників різних рівнів, що працюють в організаціях, пов'язаних з міжнародними відносинами.

Результати дослідження стилю управління, притаманного спеціалістам 3 міжнародних відносин, наведені у таблиці 1.

Як можна побачити 3 таблиці, 8 спеціалістам $(53,3 \%)$ притаманний демократичний стиль управління, 4 спеціалістам (26,7\%) - ліберальний і 3 спеціалістам (20\%) - авторитарний.

Це говорить про те, що в більшості опитаних демократичний стиль управління $є$ домінуючим. Це може пояснюватись тим, що специфіка діяльності спеціалістів міжнародних відносин вимагає демократичного підходу з огляду на те, що у світовій практиці демократичні постулати є переважаючими.

Також слід зазначити, що респонденти, для яких характерний демократичний стиль управління, більш схильні поділяти позиції ліберального підходу (на 20,4\%), аніж авторитарного $(7,4 \%)$ (рис. 1$)$.

Керівники, для яких характерний авторитарний стиль управління, на $17,3 \%$ згодні 3 позиціями ліберального підходу і на 6,2\% - демократичного. А керівники, яким притаманний ліберальний стиль управління, на 18,5\% згодні 3 позиціями демократичного підходу і на $11,1 \%$ авторитарного.

За методикою опитувальника «Велика П'ятірка» було досліджено п'ять виокремлених факторів: екстраверсія (інтроверсія); приязність (обособленість); самоконтроль (імпульсивність); емоційна стійкість (емоційна нестійкість); експресивність (практичність).

Результати дослідження особистісних характеристик спеціалістів міжнародних відносин, що займають керівні посади в організаціях, наведені в таблиці 2.

Отже, можемо зробити висновок, що більшість респондентів мають високий рівень виразності особистісних характеристик. Так, $66,6 \%$ респондентів мають високий рівень вираженості за шкалою «екстраверсія (інтроверсія)», що характеризує керівників сфери міжнародних відносин як осіб, що схильні відчувати переважно позитивні емоційні стани і почуття як щодо себе самих, так і щодо навколишнього світу. 26,8\% за цією ж шкалою мають низький рівень вираженості, що свідчить про їх меншу схильність до взаємодії з іншими людьми, певну закритість та нечасте переживання позитивних емоційних станів.

За шкалою «приязність (обособленість)» також $66,6 \%$ мають високий рівень вираженості. Для них характерні теплі відносини з іншими людьми і прагнення допомогти іншим. У $20 \%$ респондентів показник за цією шкалою має низький рівень вираженості, що свідчить про антагонізм у відносинах, недовіру, відсутність симпатії, небажання співпрацювати і грубість. Респонденти з низьким показником вираженості за шкалою «приязність (обособленість)» більше зайняті своїми персональними принципами і потребами, ніж інтересами колективу.

Також з таблиці видно, що 53,3\% респондентів мають високий рівень вираженості за шкалою «самоконтроль (імпульсивність)», це свідчить про ïх наполегливість, вмотивованість і цілеспрямованість поведінки. Також високі показники за цією шкалою свідчать про організованість, внутрішню

Відповіді респондентів на опитувальник експертної діагностики стилю управління

\begin{tabular}{|c|c|c|c|c|c|c|c|c|c|c|c|c|c|c|c|}
\hline $\begin{array}{c}\text { Респонденти/стиль } \\
\text { управління }\end{array}$ & 1 & 2 & 3 & 4 & 5 & 6 & 7 & 8 & 9 & 10 & 11 & 12 & 13 & $\mathbf{1 4}$ & $\mathbf{1 5}$ \\
\hline Авторитарний & 4 & 1 & 4 & 1 & 2 & 2 & 2 & 0 & 1 & 5 & 5 & 1 & 17 & 23 & 22 \\
\hline Ліберальний & 6 & 8 & 7 & 6 & 6 & 3 & 5 & 3 & 21 & 16 & 17 & 22 & 8 & 3 & 3 \\
\hline Демократичний & 17 & 18 & 16 & 20 & 19 & 22 & 20 & 24 & 5 & 6 & 5 & 4 & 2 & 1 & 2 \\
\hline
\end{tabular}




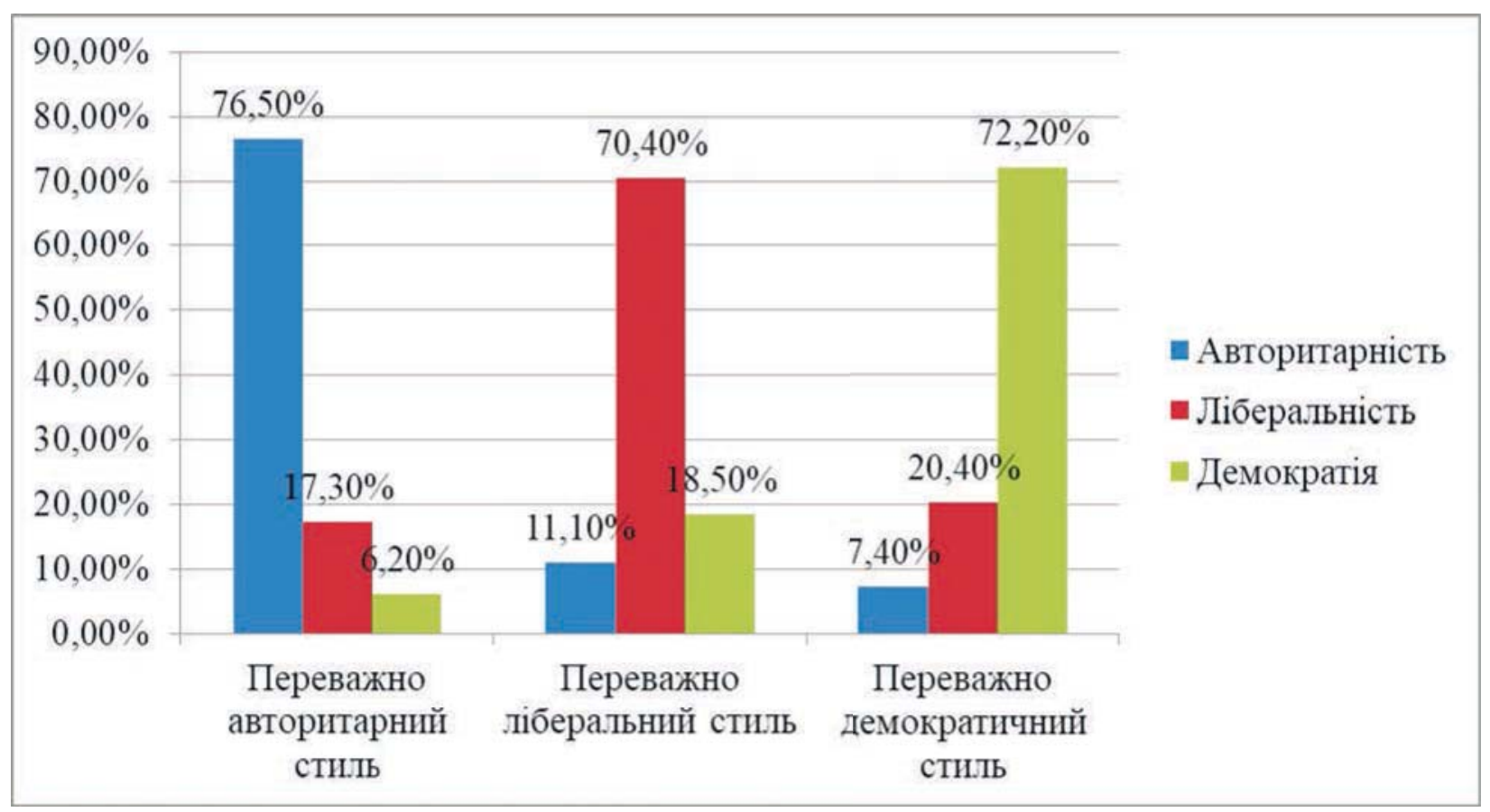

Рис. 1. Ступінь вираженості інших стилів управління у різних груп керівників

Таблиця 2

Рівні розвитку особистісних характеристик спеціалістів міжнародних відносин (у \% від загальної кількості опитаних)

\begin{tabular}{|c|c|c|c|}
\hline \multirow{2}{*}{ Особистісні характеристики } & \multicolumn{3}{|c|}{ Рівні розвитку } \\
\hline & Високий & Середній & Низький \\
\hline Екстраверсія (інтроверсія) & 66,6 & 6,6 & 26,8 \\
\hline Приязність (обособленість) & 66,6 & 13,4 & 20 \\
\hline Самоконтроль (імпульсивність) & 53,3 & 13,4 & 33,3 \\
\hline Емоційна стійкість (емоційна нестійкість) & 80 & 13,4 & 6,6 \\
\hline Експресивність (практичність) & 73,4 & 6,6 & 20 \\
\hline
\end{tabular}

Таблиця 3

Співвідношення результатів респондентів за методикою «Велика П'ятірка»

та опитувальником експертної діагностики стилю управління

\begin{tabular}{|c|c|c|c|c|c|c|c|c|}
\hline \multirow{2}{*}{$\begin{array}{c}\text { № } \\
\text { ח/ח }\end{array}$} & \multicolumn{5}{|c|}{ «Велика П’ятірка» } & \multicolumn{3}{|c|}{ Опитувальник експертної діагностики стилю управління } \\
\hline & $\mathrm{E} / \mathrm{I}$ & $\Pi / \mathrm{O}$ & $\mathrm{C} / \mathrm{I}$ & $\mathrm{EC} / \mathrm{EH}$ & $\mathrm{E} / \Pi$ & Авторитарний & Ліберальний & Демократичний \\
\hline 1 & 71 & 70 & 72 & 77 & 69 & 4 & 6 & 17 \\
\hline 2 & 73 & 71 & 71 & 79 & 77 & 1 & 8 & 18 \\
\hline 3 & 53 & 70 & 73 & 78 & 75 & 4 & 7 & 16 \\
\hline 4 & 70 & 72 & 72 & 75 & 72 & 1 & 6 & 20 \\
\hline 5 & 72 & 77 & 76 & 72 & 71 & 2 & 6 & 19 \\
\hline 6 & 75 & 80 & 79 & 70 & 73 & 2 & 3 & 22 \\
\hline 7 & 69 & 68 & 72 & 69 & 77 & 2 & 5 & 20 \\
\hline 8 & 73 & 52 & 74 & 69 & 79 & 0 & 3 & 24 \\
\hline 9 & 72 & 80 & 52 & 72 & 69 & 1 & 21 & 5 \\
\hline 10 & 71 & 71 & 55 & 78 & 43 & 5 & 16 & 6 \\
\hline 11 & 71 & $\begin{array}{l}71 \\
\end{array}$ & 47 & 42 & 72 & 5 & 17 & 5 \\
\hline 12 & 45 & $\begin{array}{l}71 \\
\end{array}$ & 45 & 41 & 72 & 1 & 22 & 4 \\
\hline 13 & 48 & 42 & 43 & 72 & 45 & 17 & 8 & 2 \\
\hline 14 & 43 & 40 & 42 & 69 & 44 & 23 & 3 & 1 \\
\hline 15 & 40 & 41 & 42 & 49 & 41 & 22 & 3 & 2 \\
\hline
\end{tabular}


дисциплінованість, пунктуальність. $33,3 \%$ респондентів мають низький рівень вираженості за цією шкалою, що свідчить про неорганізованість, спонтанність, любов до експериментів, низьку концентрацію, гедоністичність, гнучкість, слабкий контроль над імпульсами. Низький показник за цією шкалою також може свідчити про розвиток творчого потенціалу, оскільки спеціаліст міжнародних відносин залишається відкритим для різних можливостей та дій, не обираючи раз і назавжди певний шлях.

$80 \%$ респондентів мають високий рівень вираженості за шкалою «емоційна стійкість (емоційна нестійкість)», це свідчить про раціональність по відношенню до життя, спокійне ставлення до стресогенів. Такі спеціалісти 3 міжнародних відносин здаються спокійними, їх нібито не хвилюють події, які відбуваються навколо. 6,6\% респондентів за цією шкалою мають низький рівень вираженості, що свідчить про легкість виникнення у них негативних емоцій, тривожності, роздратованості.

За шкалою «експресивність (практичність)» $73,4 \%$ респондентів мають високий рівень вираженості, що характеризує спеціалістів міжнародних відносин як керівників, що відкриті новому досвіду. Вони терпимі до чужого, незвичного, толерантні до невизначеності. Відкритість досвіду має прояв у сприйнятливості до будь-якого виду знань, в активності відповідно до нових ідей або ситуацій. Такі керівники готові до експериментів та упровадження інноваційних підходів в управлінні. За цією ж шкалою $20 \%$ мають низький рівень вираженості, що свідчить про обмеженість інтересів, «консерватизм», схильність до наслідування стереотипів та традиційних способів дій.

Розглянемо співвідношення відповідей респондентів на опитувальник «Велика П'ятірка» та опитувальник експертної діагностики стилю управління (табл. 3).

Отже, з таблиці 3 ми можемо зробити висновок, що загалом вищий рівень проявленості особистісних характеристик за шкалами «Великої П'ятірки» у респондентів, що мають більші показники за шкалою демократичного стилю управління, i нижчі показники за шкалами «Великої П’ятірки» у тих респондентів, що мають більші показники за шкалою авторитарного стилю управління.

Порахувавши середній показник за шкалами «Великої П’ятірки», було виявлено, що середній показник респондентів 3 вираженим демократичним стилем управління складає 72,6 бали. Середній показник для респондентів з вираженим ліберальним стилем управління складає 62 бали. Середній показник для респондентів з вираженим авторитарним стилем складає 46,7 балів.

Можемо зробити висновок, що особистісні характеристики спеціаліста 3 міжнародних відносин міцно корелюють зі стилем управління, який їм притаманний, і можуть бути детермінантами стилю управління.

Висновки. Стиль управління як соціальнопсихологічний феномен має певну структуру. Структурні елементи стилю знаходять своєрідне виявлення, свій специфічний «рельєф» у таких основних стилях управління, як демократичний, авторитарний та ліберальний.

Емпіричне дослідження показало, що спеціалістам міжнародних відносин більш притаманний демократичний стиль управління, що може бути пов'язано $з$ тим, що демократичні постулати $€$ переважаючими у світовій практиці міжнародних відносин. Найменш характерним для спеціалістів міжнародних відносин є директивний стиль управління.

Також були знайдені зв'язки між особистісними характеристиками спеціалістів міжнародних відносин та стилем управління, який їм притаманний. Так, вищими є показники за шкалами екстраверсія (інтроверсія); приязність (обособленість); самоконтроль (імпульсивність); емоційна стійкість (емоційна нестійкість); експресивність (практичність) у тих спеціалістів, яким притаманний демократичний стиль управління, а низькі показники за цими шкалами у тих спеціалістів, для яких характерний авторитарний стиль управління.

Це дослідження $є$ емпіричною базою для подальших розвідок у сфері психології управління та менеджменту і може бути використане як основа для розробки подальшої доказової бази.

\section{Список літератури:}

1. Андрушків Б.М., Кузьмін О.С. Основи менеджменту. Львів : Світ, 1995. 296 с.

2. Виханский О.С., Наумов А.И. Менеджмент : учебник. 6-е изд., перераб. и доп. Москва : ИНФРА-М, 2015. $656 \mathrm{c}$.

3. Генов Ф. Психология управления: Основные проблемы ; пер. с болг. Москва : Прогресс, 1982. $442 \mathrm{c}$. 
4. Друкер П., Джозеф А. Менеджмент. Москва : ИД «Вильямс», 2010. 704 с.

5. Карамушка Л.М. Психологія управління : навч. посіб. для ВНЗ. Київ : Міленум, 2003. 421 с.

6. Кузьмін О.С., Мала Н.Т., МельникО.Г., Процик І.С. Керівництво організацією : навч. посіб. Львів : Вид-во НУ «Львівська політехніка», 2008. 244 с.

7. Клочко А.О. Теоретичні аспекти дослідження стилю управління в керівників освітніх організацій. Організаційна психологія 2017. № 47. С. 29-33

8. Туленков М.В. Сучасні теорії менеджменту : навч. посіб. Київ : Каравела, 2014. 304 с.

\section{Nesprava M.V. PERSONAL CHARACTERISTICS OF THE INTERNATIONAL \\ RELATIONS SPECIALIST AS A DETERMINANT OF MANAGEMENT STYLE}

The article considers the issue of personal characteristics of a specialist in international relations as determinants of management style. A general description of the concept of "management style" is given. Three main styles of management are considered: authoritarian, democratic and liberal. A complete psychological description of leaders who have an authoritarian, democratic or liberal style of management is given. It is determined that in an authoritarian style of government the leader is selfish, in a democratic style - empathetic, and in a liberal style - latent. In order to conduct an empirical study to study the relationship of management styles with the personal characteristics of specialists in international relations, we chose the method of "Big Five" to determine the personal characteristics of specialists, as well as a questionnaire of expert diagnosis of management style, to determine the inherent management style for a specialist in international relations. In the course of the study, it was determined that in the vast majority of respondents a democratic style of management is dominant. This is explained by the fact that the specifics of the activities of specialists in international relations require a democratic approach, given that in world practice, democratic postulates are predominant. It is determined that in general the higher level of manifestation of personal characteristics on the scales of the "Big Five" in respondents who have higher scores on the scale of democratic management style and lower scores on the scales of the "Big Five" in those respondents who have higher scores on scale of authoritarian style of management. Relationships have been found between the personal characteristics of international relations specialists and their management style. Thus, the indicators on the scales of extraversion (introversion); friendliness (isolation); self-control (impulsivity); emotional stability (emotional instability); expressiveness (practicality) of those specialists who have a democratic style of management are higher, and low performance on these scales in those specialists who are characterized by an authoritarian style of management. It is proved that the personal characteristics of a specialist in international relations are strongly correlated with the management style that is inherent in them and can be determinants of management style.

Key words: management style, personal characteristics of the leader, "Big Five", specialist in international relations, psychology of management. 